ikke er underordnet hinanden $i$ en dominansrelation, men gennemtrænger hinanden, leder Mortensen frem til stigningstesen (mere samfund $=$ mere individ).

Det paradoksale samfund er afgjort en original og velargumenteret bog, der rummer tankevækkende refleksioner og pointer. Ikke mindst er Mortensens kritik af og opgør med sociologiens traditionelle 'afparadokseringsstrategi' interessant, selv om det dog ikke er særlig klart, hvad det mere konkret er for en ny strategi eller nyt program for sociologisk teoriudvikling, som Mortensen har i tankerne - andet end at teorien skal kunne 'rumme' modstridende teoretiske synsvinkler og så vidt reflektere paradokserne konstruktivt. Dertil kommer, at bogen på sin vis kræver, at man som læser bekender sig til Luhmanns teori, dvs. er lige så overbevist om dennes systemteoris og paradoksbegrebs store analytiske potentiale, som forfatteren selv, og så vidt ser løsningen på sociologiens problemer som videnskab i paradoksbegrebet. Endelig kan det indvendes, at Mortensen ikke er den eneste til at påpege det moderne samfunds paradoksalitet. Det har Ulrich Beck også gjort - uden dog at gøre paradoksaliteten til omdrejningspunkt for sine analyser. Om Mortensens opfordringer og bud på en ny sociologi vil blive fulgt, vil tiden vise!

Allan Christiansen
Wittgenstein og videnskaberne

Peter C. Kjargaard: Wittgenstein og videnskaberne. Forlaget Modtryk, Aarbus 2004, 144 sider, 168 kr.

Da Georg H. von Wright for omtrent to decennier siden - i forlængelse af Anthony Kennys argumentation for, at TS 213 repræsenter et enkelt, kohærent trin i Ludwig Wittgensteins oeuvre - spurgte "Hvor mange Wittgenstein'er er der?", var spørgsmålets emne ét, der angik forfatterskabets interne brudflader. Von Wrights spørgsmål har stadig aktualitet, ikke mindst når det sættes $i$ relation til de mange forsøg på at traditionsbestemme og udrede kilderne til Wittgensteins tænkning. Læsningerne er legio. Trods de mange bio- og monografiske variationer er der enighed om, at Allan Janik \& Stephen Toulmin, Brian McGuinness og Ray Monk er pligtpensum for ethvert forsøg på at opspore de forudsatte horisonter. Dette er Peter C. Kjærgaard enig i, i sit bud Wittgenstein og videnskaberne; en studie, der kaster lys over de centrale videnskabshistoriske spørgsmål og problemkredse, som Wittgenstein overtager og søger at løse. Kjærgaards sigte og idé er mere præcist "at skabe en øget forstålse og interesse for, hvor vigtig Wittgensteins uddannelse var, hvilken betydning naturvidenskaberne havde for hans tænkning og hvilken matematikfilosofisk sammenhæng, han tænkte i” (s.8). Kjærgaards generelle tese er, "at Wittgensteins, i filosofihistorisk 
perspektiv, uforklarlige originalitet giver mening, når den ses $i$ en videnskabshistorisk sammenhæng" (s.15). Mens den singulære tese, der primært søges godtgjort er, at "Wittgensteins videnskabssyn og hans tolkning af videnskabens udvikling blev formet gennem den tidlige læsning af [...] to fysikeres [Heinrich Hertz' og Ludwig Boltzmanns] skrifter", og at disse prægede "hans referencer til og tanker om naturvidenskab resten af livet" (s.62). Her skriver jeg "primært", idet bogen desforuden anlægger flere vinkler, der berør biografi, idéhistorie, kulturhistorie, filosofihistorie, videnskabshistorie og matematikhistorie. Og selv om det $\mathrm{i}$ det anførte citat hedder "resten af livet", og selv om Kjærgaard vier et helt kapitel til den for Wittgenstein forudsatte matematiske tradition, så fremstår bogen dog fortrinsvis som et bidrag til en uddybende belysning af Tractatus logico-philosopbicus (1922). Sagt på en lidt anden måde. Med denne bog har Kjærgaard påtaget sig den opgave at udrede de mulige idé- og videnskabshistoriske linier, som Wittgenstein antyder, når han i begyndelsen af trediverne opremser en række af de personer, som har øvet indflydelse på hans tænkning. Boltzmann og Hertz anføres først i kataloget. Og da bogen tager afsæt i ovennæunte pensum (i det indledende kapitel "Wittgenstein i videnskabens tidsalder", hvori en påvirkning fra Otto Weiningers begreb om geniet og Oswald Spenglers metodiske greb om historien fremdrages), bør Kjærgaards studie først og fremmest læses dels som et korrektiv eller supplement til McGuinness', Monks og von Wrights fremstilling af Wittgenstein, dels som en forbilledlig uddybning af den første tone i Janiks \& Toulmins dobbeltgreb, og det vil sige i deres angivelse af, at Tractatus' centrale paradoks er dens bestræbelse på at forene Hertz' og Boltzmanns fysik (den "logiske" Wittgenstein) med Søren Kierkegaards og Leo Tolstoys etik (den "etiske" Wittgenstein).

Kjærgaard er bekendt med de etisk-religiøse læsninger af Wittgensteins tænkning, men vælger kun at fremdrage de træk og betoninger, som bestyrker hans sigte og teser. Ensidigheden bliver ikke ensformig, men skærper på forbilledlig vis fremstillingen af Wittgensteins biografi og tænkning. Et eksempel herpå finder vi i bogens biografiske linie: Hvor Wittgensteins indgang til filosofien hævdes (udelukkende) at gå via hans praktiske (ingeniør)arbejde i 1910-1911; her især via en videreudvikling af forbrændingsmotoren. "Konsekvensen blev", hedder det, "at han efterhånden begyndte at interessere sig for den teoretiske og matematiske konstruktion af propellen, og derigennem for matematiske problemer, deres løsninger og grundlag" (s.60). Om anledningen til Wittgensteins senere genoptagelse af det filosofiske arbejde anføres det: "Inspirationen, argumenterne og mange af de tekniske detaljer [i sin tidlige filosofi] fandt han hos Hertz. I 
modsætning til hvad mange har ment, så forsvandt den ikke med troen på at have løst alle filosofiens problemer og færdiggørelsen af Tractatus $i$ august 1918. Det var netop det, der tændte ham, da han den 10. marts 1928 hørte et foredrag $\mathrm{i}$ Wien med matematikeren Luitzen Egbertus Jan Brouwer. Det var matematikken, der først ledte Wittgenstein til filosofien og det var matematikken, der drev ham tilbage igen” (s.127). Det er altså med afsæt i denne interesse og dette arbejde, at Wittgensteins indflydelsesrige beskrivelser af sprog og verden genereres.

Kjærgaards centrale behandling af Wittgensteins formative år fra realskolen i Linz over den Tekniske Højskole i Charlottenburg til universitetet i Manchester - i "studieårene stiftede han bekendtskab med fysikerne Ludwig Boltzmanns og Heinrich Hertz' tanker" (s.61) - udfylder på eksemplarisk vis (sammen med Kelly Hamiltons studier fra 1996 og 2001) en lakune i det overleverede billede af Wittgenstein. Fremstillingen er inciterende læsning med dens vekslen mellem skole-, fag-, videnskabs- og personalhistorie. Hvem kender eksperimental-fysikeren Heinrich Rubens?

Mere alment lader Kjærgaards videnskabshistoriske kortlægninger af Wittgensteins baggrund sig opdele i to emnekredse: én der angår indflydelsen fra de to nævnte fysikere (præciseret i kapitlet "Videnskabelige baggrund") og én som angår de grundlagsspørgsmål og retninger (logicismen, formalismen og intuitionismen) inden for den filosofiske matematik (udredt i kapitlet "Matematisk tradition"), der udgør Wittgensteins pejlemærker. Dernæst følger en præcisering (i "Videnskab hos Wittgenstein") af, hvor indflydelsen fra Boltzmann, dog især fra Hertz kan registreres i Tractatus. Her træder behandlingen af Wittgensteins arbejde med den matematiske filosofi i baggrunden, men det søges blandt andet godtgjort, at der "er en tæt sammenhæng mellem Wittgensteins tidlige overvejelser over logikkens grundlag og de senere overvejelser over matematikkens grundlag fra 1927 og frem" (s.129). En central pointe for Kjærgaard er i denne sammenhæng, at Wittgensteins kritik af David Hilberts metamatematik tager sit afsæt $i$ det senfilosofiske filosofibegreb, der også bør betragtes som bestemt af Hertz; der henvises til TS 213 og det hedder: "Senere i 1939 tilskrev han [Wittgenstein] i et foredrag [...] Hertz den [...] afgørende betydning for sin filosofiske tænkemåde. I denne anledning citerede han en længere passage fra Mekanikkens principper [(1894)], hvor Hertz med henvisning til kraftbegrebet inden for mekanikken argumenterede for en måde at opløse problemer fremfor at løse dem: "Det er ikke ved at finde flere og nye sammenhænge og forbindelser, at spørgsmålet kan løses, men $i$ stedet ved at fjerne de modsigelser, der allerede findes mellem de eksisterende sammenhænge og måske derigennem at reducere deres antal. Når disse smertefulde modsigelser er fjernet, vil vores ikke længere plagede 
sind ophøre med at stille uberettigede spørgsmål”. Wittgenstein konkluderede for sit publikum, at netop denne bemærkning fra Hertz opsummerede, hvad filosofi handlede om" (s.117). Kjærgaards bog afsluttes med et mindre kapitel ("Til videre læsning"), som indeholder dels enkelte oplysninger om Wittgensteins egne skrifter, dels et udvalg af litteratur til videre læsning.

For mit eget vedkommende hæfter jeg mig især ved Kjærgaards mere eksplicitte koblinger mellem de videnskabshistoriske udredninger og Tractatus. Også i denne sammenhæng indsnævres den singulære tese til ofte udelukkende at omhandle indflydelsen fra Hertz. Disse forbindelseslinier lader sig også betragte som idéhistoriske præciseringer af Tractatus' diskussion af videnskabelige teoriers væsen (TLP 6.3 - 6.372). Eksempelvis argumenterer Kjærgaard for følgende: (a) at ideen "med at tolke forholdet mellem videnskabelige teorier om naturen og naturen selv som et forhold mellem et billede og hvad det afbilder, havde Wittgenstein overtaget fra Hertz' bog" (s.120), ja, hele "den tekniske side af billedteorien" har Wittgenstein overtaget direkte fra Hertz (s.126); (b) at Tractatus duplikerer Bolzmanns og Hertz' beskrivelse af fysiske teoriers status. "Det er også en af grundene til, at mekanikken kom til at tjene som det eksemplariske udtryk for enhver videnskabelig teori" (s.121); og (c) at ideen om at fysikken ikke forklarer naturen, men kun beskriver den har sin rod hos de to nævnte. Videnskabelige teorier er blot mulige fremstillingsformer (der søger at opfylde kriterier såsom sammenhæng, simpelhed $\mathrm{og}$ hensigtsmæssighed). - "Sætningen om årsag og virkning skulle ikke opfattes som noget, der sagde noget om verden. I stedet blev den opfattet som noget, der kun hørte til det billede, der repræsenterede naturen" (s.121). - Altså gives der mulighed for mange forskellige beskrivelser, der hver især vil indeholde arbitrære træk - "[d]enne form er vilkårlig" hedder det i Tractatus' 6.341 - og visse dækningsløse antagelser. Kjærgaard skriver: "Både Boltzmann og Hertz mente, at naturen i sig selv ikke var logisk. Men opbygningen af fysiske teorier var det nødvendigvis. Det var i den forbindelse nødvendigt for Hertz at introducere nogle mekanismer, der havde synlige effekter, selvom mekanismerne i sig selv lå uden for erfaringens grænser. Prisen for at have en samlet beskrivelse af verden ud fra et mekanisk perspektiv var begrebet "skjult masse". Ifølge Wittgenstein gjorde Hertz' skjulte masser den mekaniske beskrivelse sammenhængende. Men de medvirkede også til at synliggøre den generelle og abstrakte måde, fysiske teorier blev tolket på. "Vi må ikke glemme", skrev Wittgenstein i Tractatus, "at enhver mekanisk beskrivelse af verden må være af en fuldstændig generel karakter. Den vil for eksempel aldrig nogensinde handle om bestemte punktmasser. Den vil kun handle om en bvilken som helst punktmasse" [(TLP 6.3432)]. I krigsdagbøgerne skrev han, 
at "Hertz' usynlige masser er åbent erklærede pseudogenstande" [(NB 36)]. Der var altså intet $i$ vejen for, at enhver god teoretisk repræsentation indeholdt pseudogenstande som konstituerende elementer. Det var blot med til at vise, at teorien både var generel og uafhængig af ydre faktorer. Det var tilfældet, mente Wittgenstein, for enhver ordentlig naturvidenskabelig teori" (s.123-124). - Dette billede af videnskaben er et konventionalistisk. Kjærgaards fremhævelse og udredning af Tractatus' beskrivelse (og heriblandt den net-metaforiske illustrationen (TLP 6.342)) af naturvidenskabernes forskellige repræsentationsformer bestyrker Peter M. S. Hackers bemærkninger fra 1972 om, at senfilosofiens sprogfilosofiske position også lader sig beskrive som én, der er udarbejdet på baggrund af en generalisering af ideen om de videnskabelige teoriers verdensbeskrivelser; for så vidt forestillingen om de vilkårligt valgte beskrivelsesformer inden for videnskaberne i løbet af årene post 1929 udstrækkes til at gælde for sprog i det hele taget.

Som antydet indfrir Kjærgaard sit sigte med bogen; og den fremstår som en væsentlig påmindelse om, at mange af de gængse læsninger forbigår både betydningsfulde traditionslag og centrale emner i Wittgensteins tænkning. Kjærgaards vink er konsekvent anlagt (ikke et eneste ord om Schopenhauer, Kierkegaard, Tolstoy, James, ...), men ensidigheden bliver på ingen måde anstrengende. Tværtimod. Hvilket dog netop gør én af Wittgensteins egne metodiske anmærkninger des mere nødvendig for den opildnede læser. - "En hovedårsag til filosofiske sygdomme - ensidig diæt: man nærer sin tænkning med kun én slags eksempler” (PU §593).

Peter K. Westergaard

\section{Moral i stykker}

Theodor W. Adorno: Minima Moralia. Refleksioner fra det beskadigede liv. Oversat af Nina Lautrup-Larsen og Arno Victor Nielsen. Indledning ved Arild Linneberg. Gyldendal (serien Moderne Tankere). 2. reviderede udgave. Kobenhavn 2003.

De tre dele i Theodor W. Adornos Minima Moralia er skrevet i henholdsvis 1944, 1945 og 1946-47 - altså i de sidste krigsår og $\mathrm{i}$ tiden umiddelbart efter krigens afslutning. I den samme periode befandt Adorno sig i eksil i USA sammen med andre europæiske jøder og venstre-intellektuelle, og ikke mindst sammen med en række af de skikkelser, der - sammen med Adorno selv - udgjorde kernen i dét Institut für Sozialforschung, der var blevet nedlagt efter nazisternes magtovertagelse i Tyskland. Minima Moralia er også skrevet samtidig med, at Adorno sammen med Max Horkheimer konciperede og udarbejdede dét værk, der siden skulle gå hen og blive Adornos mest berømte: Dialektik der Aufklärung (da.: Oplysningens dialektik).

Minima Moralia bærer præg af samtidigheden med det mere kendte 